\title{
KEBIJAKAN PAJAK SELAMA PANDEMI COVID-19 DI KAWASAN ASIA TENGGARA
}

\author{
Amardianto Arham ${ }^{1}$ \\ Direktorat Jenderal Pajak \\ Amrie Firmansyah ${ }^{2}$ \\ Politeknik Keuangan Negara STAN
}

Alamat Korespondensi: arhamamardianto@gmail.com ${ }^{1}$, amrie.firmansyah@gmail.com²

\author{
INFORMASI ARTIKEL \\ Diterima Pertama \\ [14 07 2021] \\ Dinyatakan Diterima \\ [20 07 2021] \\ KATA KUNCl: \\ Kebijakan pajak, pandemi, COVID-19, \\ Asia Tenggara
}

KLASIFIKASI JEL:

$\mathrm{M} 41, \mathrm{H} 26$

\begin{abstract}
The COVID-19 pandemic that has hit many countries globally has prompted governments in various countries to respond to and overcome these problems, including tax policies. This study aims to review and compare tax policies during the COVID-19 pandemic among countries in the Southeast Asia Region. This study uses a qualitative method with content analysis and a literature review approach. This research's objects are nine countries in the Southeast Asia region, including the Philippines, Indonesia, Cambodia, Laos, Malaysia, Myanmar, Singapore, Thailand, and Vietnam. The results showed that most countries in the Southeast Asia Region focus on tax policies related to corporate income taxes. Besides, most countries in the Southeast Asia Region issued tax policies that focus on increasing corporate cash flows by providing tax incentives in the form of deferred tax payments in the early days of the pandemic and tax reductions during the economic recovery. The business sector, which was the main focus of tax policy during the pandemic in the Southeast Asia Region, was the largest contributor to gross domestic product and the sector most affected by social distancing regulations or lockdowns.
\end{abstract}

\section{ABSTRAK}

Adanya pandemi COVID-19 yang melanda banyak negara di dunia telah mendorong pemerintah di berbagai negara untuk merespon dan menanggulangi permasalahan tersebut, termasuk melalui kebijakan pajak. Penelitian ini bertujuan untuk mengulas dan membandingkan kebijakan pajak selama pandemi COVID-19 di antara negara-negara yang berada di Kawasan Asia Tenggara. Penelitian ini menggunakan metode kualitatif dengan analisis isi dan telaah literatur. Objek penelitian ini adalah sembilan negara di Kawasan Asia Tenggara yang meliputi Filipina, Indonesia, Kamboja, Laos, Malaysia, Myanmar, Singapura, Thailand, dan Vietnam. Hasil penelitian menunjukkan bahwa mayoritas negara di Kawasan Asia Tenggara berfokus pada kebijakan pajak terkait pajak penghasilan badan. Selain itu, mayoritas negara di Kawasan Asia Tenggara mengeluarkan kebijakan pajak yang berfokus pada peningkatan arus kas perusahaan melalui pemberian insentif pajak berupa penangguhan pembayaran pajak pada masa awal pandemi dan pengurangan pajak pada masa pemulihan ekonomi. Adapun sektor usaha yang menjadi fokus utama kebijakan pajak selama pandemi di Kawasan Asia Tenggara adalah sektor penyumbang produk domestik bruto terbesar dan sektor yang paling terdampak akibat adanya pembatasan sosial atau lockdown. 


\section{PENDAHULUAN}

Kasus new corona virus disease 2019 (COVID-19) pertama kali dilaporkan dari Kota Wuhan, Provinsi Hubei, China, pada 31 Desember 2019 dengan 27 kasus (Sohrabi et al., 2020; Tan et al., 2020; Xu et al., 2020; Zhu et al., 2020). Tidak lebih dari tiga bulan setelah kejadian tersebut, World Health Organization telah mendeklarasikan kasus COVID-19 ini sebagai kondisi pandemi global (Putri, 2020).

Kasus pertama COVID-19 di Kawasan Asia Tenggara dilaporkan di Thailand pada tanggal 13 Januari 2020 (Chua, 2020). Per tanggal 30 Juli 2020, wabah COVID-19 telah menyebar di seluruh negara di Kawasan Asia Tenggara dengan jumlah total kasus yang telah mencapai 263.973 kasus (Chua, 2020). Hal tersebut berarti bahwa jumlah kasus COVID-19 rata-rata harian di Asia Tenggara mencapai angka 1.339 kasus per hari. Angka tersebut menunjukkan bahwa laju lonjakan kasus COVID-19 di Kawasan Asia Tenggara cukup cepat.

Cepatnya laju penambahan jumlah kasus COVID-19 di Kawasan Asia Tenggara menyebabkan pemerintah setempat memberlakukan kebijakan pembatasan sosial atau lockdown (Nugroho, 2020). Adanya pembatasan sosial tersebut menyebabkan lesunya perekonomian di Kawasan Asia Tenggara (Jayani, 2020). Bagi Kawasan Asia Tenggara yang tingkat perekonomiannya menduduki posisi terbesar ketujuh di dunia dan terbesar ketiga di Asia (World Economic Forum, 2016), adanya pandemi COVID-19 memberikan dampak langsung yang signifikan terhadap perekonomian negara-negara di kawasan ini (Fauzi \& Paiman, 2020). Oleh karena itu, upaya-upaya perlu dilakukan oleh pemerintah di negara-negara yang berada di Kawasan Asia Tenggara untuk menjaga stabilitas perekonomian di tengah krisis akibat pandemi COVID-19. Salah satu instrumen yang dapat digunakan adalah kebijakan fiskal yang meliputi kebijakan terkait perpajakan (Horton \& ElGanainy, 2020).

Dalam kondisi perekonomian yang sedang lesu, kebijakan pajak dapat difokuskan pada pemberian berbagai keringanan atau insentif pajak agar daya beli dan tingkat konsumsi masyarakat dapat tetap terjaga (Darussalam, 2020). Selain itu, kebijakan pajak yang responsif dan tepat sasaran sangat diperlukan dalam kondisi pandemi (OECD, 2020a). Kondisi tersebut mendorong Organisation for Economic Co-operation and Development (OECD) untuk menerbitkan kerangka kebijakan pajak yang dapat diimplementasikan oleh negara-negara di dunia selama masa pandemi COVID19, termasuk negara-negara yang berada di Kawasan Asia Tenggara.

Beberapa penelitian terdahulu telah mengulas mengenai keterkaitan pandemi COVID-19 dengan perpajakan. Clemens \& Veuger (2020) telah membahas mengenai dampak pandemi COVID-19 terhadap penerimaan pajak di Amerika Serikat. Terkait kebijakan pajak di masa pandemi COVID-19, Avi-Yonah (2020) telah mengulas seperti apa kebijakan pajak yang telah diterapkan di Amerika Serikat. Selain itu, Pomerleau (2020) secara lebih spesifik mengulas mengenai kebijakan pajak yang diimplementasikan oleh pemerintah federal di Amerika Serikat selama pandemi COVID-19. Akan tetapi, penelitian terdahulu yang mengulas mengenai keterkaitan pajak dengan kondisi pandemi COVID-19 di Kawasan Asia Tenggara masih jarang dilakukan. Penelitian terdahulu mengenai perpajakan di Kawasan Asia Tenggara hanya mengulas tentang keterkaitan globalisasi dengan sistem pajak di Kawasan Asia Tenggara (Asher \& Rajan, 2001). Oleh karena itu, keterkaitan pandemi COVID-19 dengan pajak khususnya kebijakan pajak di Kawasan Asia Tenggara masih perlu untuk diinvestigasi lebih lanjut.

Berdasarkan uraian mengenai pentingnya kebijakan pajak selama pandemi COVID-19 dan masih minimnya penelitian terdahulu mengenai topik tersebut di Kawasan Asia Tenggara, pemetaan perlu untuk dilakukan. Akan tetapi, penelitian-penelitian terdahulu terkait topik pandemi COVID-19 di Asia Tenggara hanya mengulas mengenai upaya pengendalian penularan wabah (Fauzi \& Paiman, 2020), dampak terhadap lingkungan (Kanniah et al., 2020), serta dampak terhadap sistem pelatihan petugas kesehatan (Wittayanakorn, et al., 2020). Oleh karena itu, penelitian ini diharapkan dapat mengisi kesenjangan penelitian yang telah ada.

Penelitian ini bertujuan untuk mengulas dan membandingkan kebijakan pajak selama pandemi COVID-19 di Kawasan Asia Tenggara. Penelitan ini diharapkan dapat memberikan gambaran yang komprehensif mengenai kebijakan pajak yang diterapkan oleh negara-negara di Kawasan Asia Tenggara di tengah pandemi COVID-19. Selain itu, penelitian ini juga diharapkan dapat menjadi bahan pertimbangan dalam penyusunan alternatif kebijakan pajak selama masa pandemi COVID-19.

\section{KERANGKA TEORI DAN PENGEMBANGAN HIPOTESIS}

\subsection{Fungsi Pajak}

Menurut Mardiasmo (2018), ada dua fungsi pajak yaitu fungsi anggaran (budgetair) dan fungsi mengatur (regulerend). Pajak berfungsi sebagai salah satu sumber dana bagi pemerintah untuk membiayai pengeluaran dalam penyelenggaraan kehidupan bernegara. Pajak juga berfungsi sebagai alat untuk mengatur atau melaksanakan kebijakan pemerintah dalam bidang sosial dan ekonomi. Pajak dapat digunakan oleh pemerintah untuk mengatur masyarakatnya agar mencapai tujuan-tujuan tertentu.

\subsection{Kerangka OECD}

Berdasarkan kerangka acuan yang dipublikasikan oleh OECD (2020a) sebagaimana dapat dilihat pada 
Gambar 1, ada empat fase atau tahap dalam kerangka acuan kebijakan pajak yang dapat diterapkan selama masa pandemi COVID-19. Fase pertama merupakan fase ketika pemerintah memberikan respon awal terhadap terjadinya kondisi pandemi. Pada fase ini, kebijakan pajak perlu menjadi bagian dari keseluruhan paket kebijakan pemerintah. Kebijakan pajak perlu diselaraskan dengan kebijakan pemerintah lainnya terutama yang berkaitan dengan belanja pemerintah, aspek kesehatan, bidang keuangan, dan bidang moneter. Selain itu, pada fase ini, kebijakan pajak dapat difokuskan pada pemberian dukungan dalam rangka menjaga likuiditas dan pendapatan baik bagi perusahaan atau sektor bisnis maupun rumah tangga. OECD (2020a) juga memberikan gambaran mengenai beberapa kebijakan pajak yang diambil oleh negaranegara anggota OECD maupun negara-negara anggota G20 selama masa awal terjadinya pandemi COVID-19. Fokus utama kebijakan pajak di beberapa negara anggota OECD maupun beberapa negara anggota G20 adalah pemberian dukungan kepada perusahaanperusahaan agar tetap dapat menjaga ketersediaan arus kas yang memadai (OECD, 2020a). Di negara-negara anggota OECD dan G20, bentuk dukungan pemerintah tersebut mayoritas diwujudkan dalam bentuk pemberian insentif pajak berupa penangguhan pembayaran pajak.

Selanjutnya, fase kedua merupakan fase lanjutan dari fase pertama. Pada fase ini, upaya pemerintah untuk menjaga likuiditas dan melakukan mitigasi masih berlangsung sehingga respon kebijakan pajak yang berkelanjutan sangat diperlukan. Pada fase ini, pemerintah perlu selalu melakukan penyesuaian dan dimungkinkan untuk memperluas rangkaian kebijakan pajak yang sudah diterapkan. Lamanya pembatasan sosial atau lockdown yang diterapkan oleh pemerintah dapat berdampak pada kondisi keuangan perusahaan meskipun pemerintah telah memberikan dukungan likuiditas. Terkait hal tersebut, kebijakan pajak yang dapat diberikan oleh pemerintah kepada perusahaan pada fase ini tidak hanya terbatas pada perpanjangan waktu untuk penangguhan pembayaran pajak tetapi juga dapat meliputi pengurangan tarif pajak. Pengurangan tarif pajak yang diberikan oleh pemerintah dapat bersifat temporer. Pemerintah juga dapat mempertimbangkan untuk memberikan pembebasan atas jenis-jenis pajak tertentu, seperti pajak atas properti. Selain itu, pemerintah juga dapat mempertimbangkan untuk mempercepat proses pengembalian pajak pertambahan nilai (PPN) yang dapat meningkatkan arus kas perusahaan. Seiring dengan berlanjutnya krisis, yang juga tidak kalah penting adalah penguatan dukungan bagi sektor rumah tangga yang memiliki risiko yang lebih besar untuk kehilangan pekerjaan dan pendapatan.

Fase ketiga merupakan fase pemulihan. Pada fase ini, kebijakan pajak dapat difokuskan pada pemberian stimulus fiskal yang dapat mendukung investasi dan konsumsi. Menumpuknya utang perusahaan dan rumah tangga, meningkatnya penutupan bisnis dan pengangguran, serta meningkatnya ketidakpastian ekonomi dapat mengurangi investasi dan konsumsi di masa depan. Stimulus fiskal yang diberikan oleh pemerintah perlu diatur waktunya dengan hati-hati dan perlu dikawal dengan baik agar tepat sasaran. Di samping itu, kebijakan pajak yang dikeluarkan oleh pemerintah perlu menyesuaikan dengan kondisi khusus negara yang bersangkutan. Pada tahap ini, koordinasi dalam penyusunan dan implementasi kebijakan merupakan kunci untuk mewujudkan kebijakan pajak yang efektif.

Pada fase keempat, fokus kebijakan pajak dapat beralih kepada kebijakan untuk memulihkan keuangan negara. Keuangan negara mengalami tekanan yang cukup besar sebagai akibat dari berbagai kebijakan pajak dalam bentuk dukungan yang diberikan kepada sektor bisnis dan rumah tangga pada fase-fase sebelumnya. Setelah pulihnya perekonomian, pemerintah perlu menyusun langkah-langkah untuk meningkatkan pendapatan negara yang mengarah pada kesinambungan fiskal jangka panjang. Hal tersebut perlu dilakukan karena pemerintah membutuhkan pendanaan untuk memulai atau melanjutkan investasi pemerintah, meningkatkan sistem pelayanan kesehatan, serta mengantisipasi berbagai risiko jangka panjang lainnya. Akan tetapi, upaya peningkatan pendapatan negara perlu diatur waktunya dengan baik dan dilakukan dengan hati-hati agar konsisten dengan aspek pertumbuhan, aspek inklusivitas, serta aspek keberlanjutan. 
Gambar 1. Kerangka Kebijakan Pajak Selama Pandemi COVID-19

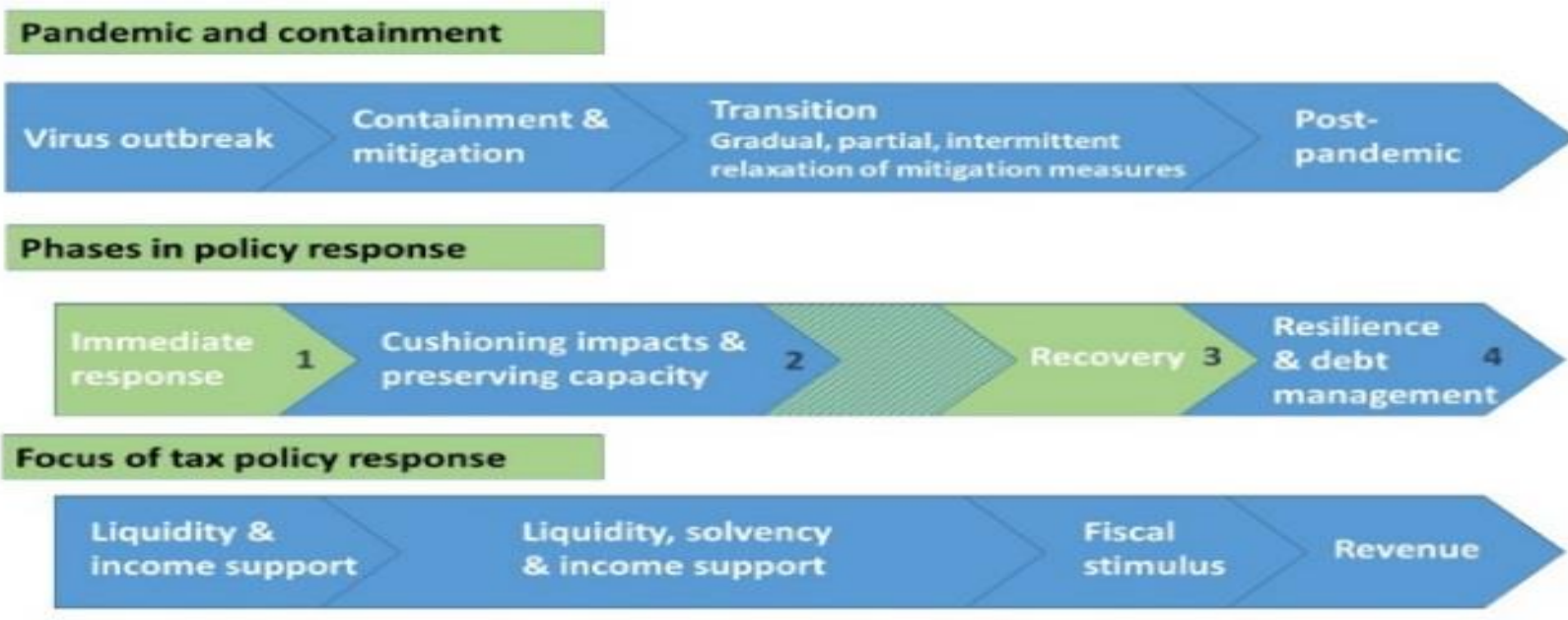

Sumber: OECD (2020a)

\section{METODE PENELITIAN}

Penelitan ini menggunakan metode kualitatif yaitu analisis isi dan telaah literatur. Analisis isi dilakukan dengan mengambil informasi-informasi yang digunakan dalam penelitian ini dari laporan "Overview of Country Tax Policy Measures in Response to Covid-19 Crisis" yang diterbitkan OEDC di tahun 2020. Adapun informasiinformasi dari laporan tersebut yang didapatkan dari analisis isi yaitu meliputi kebijakan pajak berdasarkan jenis pajak, fase kebijakan pajak, kebijakan pajak berdasarkan bentuk respon terhadap krisis, jenis insentif pajak sebagai respon terhadap krisis, jenis insentif pajak sebagai bentuk pemulihan ekonomi.

Objek dari penelitian ini adalah sembilan negara di Kawasan Asia Tenggara, yaitu Filipina, Indonesia, Kamboja, Laos, Malaysia, Myanmar, Singapura, Thailand, dan Vietnam. Pemilihan objek ini didasarkan pada kelengkapan data yang diperoleh dalam proses analisis isi. Selanjutnya, data yang diperoleh dari hasil analisis isi digunakan sebagai dasar untuk melakukan pemetaan sesuai dengan informasi yang diulas dengan membandingkan data setiap negara. Ulasan atas data tersebut dilakukan dengan menggunakan artikel jurnal dan sumber daring lainnya.

\section{HASIL PENELITIAN}

Merujuk pada data yang dihimpun oleh OECD (2020b) mengenai overview kebijakan pajak yang telah diimplementasikan oleh 123 negara di dunia (baik yang merupakan anggota OECD maupun yang bukan anggota OECD) per tanggal 30 Juli 2020, penelitian ini mencoba untuk memetakan secara khusus berbagai kebijakan pajak yang telah diterapkan oleh beberapa negara di Kawasan Asia Tenggara yaitu, Filipina, Indonesia, Kamboja, Laos, Malaysia, Myanmar, Singapura, Thailand, dan Vietnam. Pertama, penelitian ini memetakan kebijakan pajak berdasarkan jenis pajak yang telah diterapkan oleh negara-negara tersebut selama pandemi COVID-19 sebagaimana dapat dilihat pada Tabel 1.

Tabel 1. Pemetaan Kebijakan Pajak Berdasarkan Jenis Pajak

\begin{tabular}{lcccccc}
\hline \multirow{2}{*}{ Negara } & \multicolumn{7}{c}{ Jenis Pajak } \\
\cline { 2 - 6 } & PIT & CIT & $\begin{array}{c}\text { Pajak } \\
\text { Properti }\end{array}$ & VAT & $\begin{array}{c}\text { Pajak Konsumsi } \\
\text { Lainnya }\end{array}$ & Lainnya \\
\hline Filipina & & $\mathrm{V}$ & & $\mathrm{V}$ & $\mathrm{V}$ & $\mathrm{V}$ \\
Indonesia & $\mathrm{V}$ & $\mathrm{V}$ & & $\mathrm{V}$ & $\mathrm{V}$ & $\mathrm{V}$ \\
Kamboja & $\mathrm{V}$ & $\mathrm{V}$ & $\mathrm{V}$ & & $\mathrm{V}$ & $\mathrm{V}$ \\
Laos & $\mathrm{V}$ & $\mathrm{V}$ & & & & $\mathrm{V}$ \\
Malaysia & $\mathrm{V}$ & $\mathrm{V}$ & & & & $\mathrm{V}$ \\
Myanmar & $\mathrm{V}$ & $\mathrm{V}$ & & & $\mathrm{V}$ & $\mathrm{V}$ \\
Singapura & & $\mathrm{V}$ & $\mathrm{V}$ & & & \\
Thailand & & $\mathrm{V}$ & & $\mathrm{V}$ & $\mathrm{V}$ & \\
Vietnam & $\mathrm{V}$ & $\mathrm{V}$ & & $\mathrm{V}$ & &
\end{tabular}


Keterangan:

PIT: Personal Income Tax (PPh Orang Pribadi)

CIT: Corporate Income Tax (PPh Badan)

VAT: Value Added Tax (Pajak Pertambahan Nilai)

Tabel 1 menunjukkan bahwa selama pandemi COVID-19, sebagian besar negara di Kawasan Asia Tenggara mengeluarkan kebijakan pajak yang berkaitan dengan pajak penghasilan (PPh) bagi korporasi atau badan. Sementara itu, kebijakan pajak yang paling sedikit diterapkan di negara-negara yang berada di Kawasan Asia Tenggara di tengah pandemi COVID-19 adalah kebijakan pajak yang berkaitan dengan pajak properti.

Berikutnya, penelitian ini memetakan kebijakan pajak di Kawasan Asia Tenggara berdasarkan fase kebijakan pajak yang mengacu pada kerangka OECD sebagaimana ditunjukkan pada Tabel 2.

Tabel 2. Pemetaan Berdasarkan Fase Kebijakan Pajak

\begin{tabular}{lcc}
\hline \multirow{2}{*}{ Negara } & \multicolumn{2}{c}{ Fase Kebijakan Pajak } \\
\cline { 2 - 3 } & $\begin{array}{c}\text { Respon terhadap } \\
\text { Krisis }\end{array}$ & $\begin{array}{c}\text { Pemulihan } \\
\text { Ekonomi }\end{array}$ \\
\hline Filipina & $\mathrm{V}$ & \\
Indonesia & $\mathrm{V}$ & $\mathrm{V}$ \\
Kamboja & $\mathrm{V}$ & \\
Laos & $\mathrm{V}$ & $\mathrm{V}$ \\
Malaysia & $\mathrm{V}$ & \\
Myanmar & $\mathrm{V}$ & \\
Singapura & $\mathrm{V}$ & \\
Thailand & $\mathrm{V}$ & $\mathrm{V}$ \\
Vietnam & $\mathrm{V}$ & \\
\hline
\end{tabular}

Sumber: Diolah dari OECD (2020b)

Tabel 2 memberikan informasi bahwa mayoritas negara di Kawasan Asia Tenggara masih berada pada fase pertama dan fase kedua sehingga masih berfokus pada kebijakan pajak yang bertujuan untuk merespon dengan segara kondisi krisis yang sedang terjadi akibat pandemi COVID-19. Hal ini berarti bahwa pada umumnya negara-negara di Kawasan Asia Tenggara masih berkutat pada upaya penanggulangan penularan wabah COVID-19 di masing-masing negara.

Adapun bentuk respon terhadap krisis akibat pandemi COVID-19 yang dilakukan oleh negara-negara di Kawasan Asia Tenggara dapat dilihat pada Tabel 3.
Tabel 3. Pemetaan Kebijakan Pajak Berdasarkan Bentuk Respon terhadap Krisis

\begin{tabular}{|c|c|c|c|c|c|c|}
\hline \multirow{2}{*}{ Negara } & \multicolumn{6}{|c|}{ Bentuk Respon terhadap Krisis } \\
\hline & A & B & C & D & $\mathbf{E}$ & $\mathbf{F}$ \\
\hline Filipina & & & $\sqrt{ }$ & & & \\
\hline Indonesia & $\sqrt{ }$ & $\sqrt{ }$ & $\sqrt{ }$ & & $\sqrt{ }$ & \\
\hline Kamboja & $\sqrt{ }$ & v & & & $v$ & $\sqrt{ }$ \\
\hline Laos & $\sqrt{ }$ & $\sqrt{ }$ & $\sqrt{ }$ & & & \\
\hline Malaysia & $\sqrt{ }$ & & & $\sqrt{ }$ & & $\sqrt{ }$ \\
\hline Myanmar & $\sqrt{ }$ & & & & & \\
\hline Singapura & $\sqrt{ }$ & & & & $\sqrt{ }$ & $\sqrt{ }$ \\
\hline Thailand & $\sqrt{ }$ & & $\sqrt{ }$ & & & $\sqrt{ }$ \\
\hline Vietnam & $\sqrt{ }$ & & & & & \\
\hline
\end{tabular}

Keterangan:

A: Peningkatan arus kas perusahaan

B: Peningkatan arus kas rumah tangga

C: Dukungan terhadap sistem kesehatan

D: Dukungan terhadap konsumsi

E: Dukungan terhadap pekerja

F: Dukungan terhadap investasi

Berdasarkan Tabel 3, pada fase respon terhadap krisis (fase pertama dan fase kedua), mayoritas negara di Kawasan Asia Tenggara memilih untuk menerapkan kebijakan pajak yang dapat meningkatkan arus kas perusahaan di tengah situasi pandemi COVID-19. Hal ini sesuai dengan panduan yang diberikan oleh OECD dan juga sejalan dengan praktik yang dilakukan di negara-negara anggota OECD dan G20 (OECD, 2020a). Sementara itu, bentuk respon terhadap krisis yang paling sedikit diterapkan di Kawasan Asia Tenggara adalah pemberian kebijakan pajak untuk mendukung kegiatan konsumsi masyarakat.

Di Kawasan Asia Tenggara, kebijakan pajak dalam rangka meningkatkan arus kas perusahaan diberikan kepada perusahaan yang bergerak di sektor-sektor tertentu. Pemerintah Filipina memberikan keringanan pajak pada industri yang memproduksi alat-alat kesehatan (Bureau of Internal Revenue, 2020). Di Indonesia, pemerintah memberikan keringanan pajak terhadap perusahaan yang bergerak di sektor perdagangan, industri, jasa, akomodasi, serta makanan dan minuman (Kementerian Keuangan Republik Indonesia, 2020). Di Kamboja, keringanan pajak diberikan oleh pemerintah untuk meningkatkan arus kas pada perusahaan yang bergerak di sektor perhotelan, restoran, dan agen perjalanan (Kurniati, 2020). Adapun pemerintah Laos memberikan keringanan pajak terhadap perusahaan di sektor pariwisata (VDB Loi, 2020). Sementara itu, Malaysia memilih sektor perhotelan untuk diberikan keringanan pajak dalam rangka mendorong peningkatan arus kas perusahaan (EY, 2020). Adapun pemerintah Myanmar memberikan keringanan pajak bagi sektor pariwisata dan perhotelan (KPMG, 2020). Di Singapura, pemerintah memberikan keringanan pajak terhadap 
perusahaan perhotelan dan pelayaran (Inland Revenue Authority of Singapore, 2020). Sementara itu, di Thailand, pemerintah memberikan keringanan pajak terhadap usaha kecil dan menengah (Krailadsiri \& Chaisechotes, 2020). Adapun di Vietnam, pemerintah memberikan keringanan pajak untuk meningkatkan arus kas perusahaan yang bergerak di sektor pertanian, kehutanan, manufaktur, pariwisata, dan transportasi (Orbitax, 2020).

Berdasarkan uraian di atas, secara umum, mayoritas negara di Kawasan Asia Tenggara memberikan keringanan pajak pada sektor perhotelan dan pariwisata. Kedua sektor ini dapat diduga menjadi fokus utama kebijakan pajak selama pandemi COVID19 karena merupakan sektor yang terdampak cukup signifikan akibat adanya pemberlakuan pembatasan aktivitas masyarakat di luar rumah. Adanya pembatasan sosial atau lockdown menyebabkan operasional bisnis kedua sektor tersebut terganggu bahkan terhenti dalam waktu yang cukup lama sehingga kedua sektor tersebut mengalami pengurangan pendapatan, berkurangnya arus kas, bahkan dapat memicu pengurangan jumlah karyawan atau terjadinya pemutusan hubungan kerja. Dengan demikian, hal tersebut juga telah selaras dengan fungsi pajak sebagai pengatur (regulerend) yang diwujudkan melalui pemberian kebijakan pajak dalam rangka stabilisasi ekonomi di suatu negara. Di Asia Tenggara, bentuk konkret hal tersebut adalah pemberian keringanan pajak terhadap sektor usaha yang terdampak selama pandemi COVID-19 untuk menjamin keberlangsungan sektor usaha tersebut.

Selanjutnya, penelitian ini membandingkan sektor yang menjadi fokus utama kebijakan pajak selama pandemi COVID-19 di masing-masing negara dengan sektor penyumbang terbesar produk domestik bruto (PDB) di masing-masing negara di Kawasan Asia Tenggara. Sektor manufaktur dan jasa merupakan dua sektor utama yang menjadi penyumbang terbesar dalam PDB di Kawasan Asia Tenggara (Trading Economics, 2020). Negara-negara yang mengandalkan sektor manufaktur dalam PDB-nya adalah Indonesia, Myanmar, Singapura, dan Thailand. Sementara itu, Filipina, Kamboja, Laos, dan Vietnam bertumpu pada sektor jasa dalam PDB.

Jika dikaitkan dengan kebijakan pajak selama pandemi COVID-19 yang telah diambil oleh masingmasing negara, mayoritas negara di Kawasan Asia Tenggara (Indonesia, Kamboja, Laos, Malaysia, Thailand, Vietnam) telah memilih sektor penyumbang terbesar PDB di tiap negara untuk menjadi fokus pemberian insentif pajak. Sementara itu, Myanmar dan Singapura yang memiliki sumber PDB terbesar dari sektor manufaktur ternyata tidak menjadikan sektor tersebut sebagai fokus utama pemberian insentif pajak di masa pandemi COVID-19. Kedua negara tersebut memilih untuk memberikan insentif pajak selama pandemi COVID-19 terhadap sektor jasa yaitu sektor pariwisata, sektor perhotelan, dan sektor transportasi. Hal yang mendasari kebijakan kedua negara tersebut dapat diduga adalah pertimbangan mengenai sektor yang paling terdampak akibat adanya pembatasan sosial atau lockdown. Sementara itu, hal yang berbeda dapat dilihat pada negara Filipina yang mengandalkan PDB-nya pada sektor jasa. Selama pandemi COVID-19, ternyata Filipina tidak memilih sektor tersebut sebagai penerima insentif pajak, tetapi memilih sektor manufaktur, khususnya produsen alat-alat kesehatan. Kemungkinan, hal yang mendasari pengambilan kebijakan pajak di negara tersebut adalah pertimbangan mengenai upaya untuk memaksimalkan peran perusahaan domestik dalam mendukung pengadaan alat-alat kesehatan sebagai penunjang percepatan penanggulangan wabah COVID-19 di negara tersebut.

Selanjutnya, penelitian ini menelusuri lebih lanjut jenis insentif pajak yang telah diberikan oleh negaranegara di Kawasan Asia Tenggara sebagai bentuk respon terhadap krisis akibat pandemi COVID-19.

Tabel 4. Pemetaan Jenis Insentif Pajak sebagai Respon terhadap Krisis

\begin{tabular}{|c|c|c|c|c|c|c|}
\hline \multirow[t]{2}{*}{ Negara } & \multicolumn{6}{|c|}{$\begin{array}{c}\text { Jenis Insentif Pajak sebagai } \\
\text { Respon terhadap Krisis }\end{array}$} \\
\hline & A & B & C & D & E & $\mathbf{F}$ \\
\hline Filipina & & & & & & V \\
\hline Indonesia & & v & & V & V & V \\
\hline Kamboja & & & & & V & V \\
\hline Laos & & & & & v & V \\
\hline Malaysia & & & & & V & \\
\hline Myanmar & & & & & v & \\
\hline Singapura & V & & v & & V & V \\
\hline Thailand & & & & v & V & \\
\hline Vietnam & & & & & v & \\
\hline
\end{tabular}

Sumber: Diolah dari OECD (2020b)

Keterangan:

A: Percepatan penyusutan

B: Pengurangan tarif PPh Badan

C: Pengurangan tariff PPh Orang Pribadi

D: Percepatan pengembalian pajak

E: Penangguhan pembayaran pajak

F: Pembebasan pajak

Berdasarkan Tabel 4, jenis insentif pajak yang paling banyak diberikan di Kawasan Asia Tenggara adalah penangguhan pembayaran pajak. Hal ini sejalan dengan praktik kebijakan pajak yang juga telah diterapkan oleh negara-negara anggota OECD dan G20.

Sebagaimana ditampilkan pada Tabel 2, per 30 Juli 2020, telah ada tiga dari sembilan negara di Kawasan Asia Tenggara (Kamboja, Malaysia, Vietnam) yang sudah memasuki fase ketiga atau fase pemulihan ekonomi. Selanjutnya, penelitian ini memetakan bentuk pemulihan ekonomi yang dilakukan beserta jenis insentif pajak yang diberikan oleh ketiga negara tersebut sebagaimana ditampilkan pada Tabel 5. 
Tabel 5. Pemetaan Jenis Insentif Pajak sebagai Bentuk Pemulihan Ekonomi

\begin{tabular}{|c|c|c|}
\hline Negara & $\begin{array}{c}\text { Bentuk } \\
\text { Pemulihan } \\
\text { Ekonomi }\end{array}$ & $\begin{array}{c}\text { Jenis Insentif } \\
\text { Pajak }\end{array}$ \\
\hline Kamboja & $\begin{array}{l}\text { Peningkatan } \\
\text { investasi }\end{array}$ & $\begin{array}{c}\text { Pengurangan tarif } \\
\text { pajak }\end{array}$ \\
\hline Malaysia & $\begin{array}{l}\text { Peningkatan } \\
\text { konsumsi \& } \\
\text { investasi }\end{array}$ & $\begin{array}{c}\text { Pengurangan dan } \\
\text { pembebasan } \\
\text { pajak }\end{array}$ \\
\hline Vietnam & $\begin{array}{l}\text { Peningkatan arus } \\
\text { kas perusahaan }\end{array}$ & $\begin{array}{c}\text { Pengurangan tarif } \\
\text { pajak }\end{array}$ \\
\hline
\end{tabular}

Berdasarkan informasi pada Tabel 5, pada fase pemulihan ekonomi, negara-negara di Kawasan Asia Tenggara berfokus pada pemberian kebijakan pajak berupa pengurangan pajak. Hal ini sejalan dengan kebijakan pajak yang dilakukan oleh pemerintah federal Amerika Serikat, yang juga memberikan kebijakan pengurangan pajak baik bagi orang pribadi maupun perusahaan (Pomerleau, 2020).

Dalam penelitian ini, analisis kebijakan pajak selama pandemi COVID-19 di Kawasan Asia Tenggara hanya dilakukan sampai dengan fase ketiga. Untuk fase keempat atau fase pemulihan keuangan negara, analisis belum dapat dilakukan karena hingga penelitian ini dilakukan dan merujuk pada data publikasi OECD yang digunakan per tanggal 30 Juli 2020, belum ada negara di Asia Tenggara yang berada di fase keempat. Akan tetapi, sebagaimana praktik pada fase-fase sebelumnya, praktik kebijakan pajak yang dikeluarkan oleh negara-negara di Asia Tenggara juga diperkirakan sejalan dengan panduan kerangka kebijakan pajak yang dikeluarkan oleh OECD (2020a).

Pada fase keempat atau fase pemulihan keuangan negara, negara-negara di Kawasan Asia Tenggara dapat mengeksplorasi berbagai pilihan untuk melakukan reformasi kebijakan pajak (OECD, 2020a). Beberapa akademisi dan para pemangku kepentingan telah memberikan rekomendasi langkah-langkah peningkatan pendapatan pajak yang tidak biasa (Guvenen et al., 2019; Landais et al., 2020). Marron (2020) dan Mankiw (2020) telah merekomendasikan penggunaan sistem pajak untuk memajaki kembali penghasilan tambahan yang diperoleh selama masa krisis akibat pandemi. Selain itu, isu untuk mengenakan pajak atas emisi karbon juga menguat sebagai salah satu cara untuk mengkombinasikan tujuan pencapaian penerimaan pajak dengan suatu hal yang bersifat lebih fundamental dan merupakan bentuk reformasi jangka panjang (OECD, 2020a).

Pemerintah di negara-negara yang berada di Kawasan Asia Tenggara juga dapat mempertimbangkan untuk menambah basis pajak baru maupun mengoptimalkan penggalian potensi pajak pada basis pajak yang sudah ada. Dalam hal pemerintah setempat perlu untuk meningkatkan pendapatan pajak, upaya yang dilakukan dapat berfokus pada penggalian potensi pajak pada basis pajak atau sektor yang paling tidak berdampak negatif terhadap pertumbuhan ekonomi, seperti pajak berulang atas harta tak bergerak dan pajak atas konsumsi umum. Analisis lebih lanjut perlu dilakukan oleh pemerintah termasuk otoritas pajak di masingmasing negara yang berada di Kawasan Asia Tenggara mengingat bahwa upaya untuk memulihkan keuangan negara belum dimulai dan mungkin akan memakan waktu yang cukup lama. Hal tersebut seharusnya juga dapat menjadi dasar untuk mengkaji secara mendalam terkait kemungkinan perlunya sebuah reformasi pajak di Kawasan Asia Tenggara.

\section{KESIMPULAN DAN SARAN}

Penelitian ini bertujuan untuk mengulas dan membandingkan kebijakan pajak selama pandemi COVID-19 di Kawasan Asia Tenggara yang meliputi negara Filipina, Indonesia, Kamboja, Laos, Malaysia, Myanmar, Singapura, Thailand, dan Vietnam. Hasil penelitian ini menunjukkan bahwa mayoritas negara di Kawasan Asia Tenggara berfokus pada kebijakan pajak yang berkaitan dengan pajak penghasilan badan. Pada masa awal pandemi COVID-19, mayoritas negara di Kawasan Asia Tenggara mengeluarkan kebijakan pajak yang berfokus pada peningkatan arus kas perusahaan melalui pemberian insentif pajak berupa penangguhan pembayaran pajak. Adapun pada masa pemulihan ekonomi, mayoritas negara di Asia Tenggara berfokus pada pemberian insentif pajak berupa pengurangan pajak. Sektor usaha yang menjadi fokus utama kebijakan pajak selama pandemi di Kawasan Asia Tenggara adalah sektor penyumbang produk domestik bruto terbesar dan sektor yang paling terdampak akibat adanya pembatasan sosial atau lockdown.

Penelitian ini memiliki keterbatasan yaitu hanya mengulas mengenai kebijakan pajak selama pandemi COVID-19 di Kawasan Asia Tenggara berdasarkan kerangka acuan yang dipublikasikan oleh OECD (2020a). Penelitian selanjutnya dapat menambahkan beberapa acuan atau panduan kebijakan pajak lainnya agar dapat membandingkan dan merekomendasikan panduan kebijakan pajak yang tepat bagi setiap negara di Kawasan Asia Tenggara. Selain itu, penelitian ini hanya menggunakan beberapa negara di Kawasan Asia Tenggara sebagai objek penelitian. Penelitian berikutnya dapat menggunakan negara-negara lainnya di luar di Kawasan Asia Tenggara sebagai objek penelitian atau menggunakan beberapa kawasan di dunia agar dapat membandingkan penerapan kebijakan pajak selama pandemi COVID-19 antarkawasan di dunia. Penelitian selanjutnya juga dapat menambahkan ulasan mengenai kebijakan pajak yang tepat selama pandemi yang diperoleh dari hasil wawancara terhadap para pakar baik yang berasal dari masing-masing negara yang berada di Kawasan Asia Tenggara maupun negara-negara lainnya di dunia. Hasil penelitian ini dapat menjadi bahan masukan bagi pemerintah maupun otoritas pajak baik di negaranegara yang berada di Kawasan Asia Tenggara. Penelitian ini juga dapat menjadi indikasi bagi Direktorat Jenderal Pajak selaku otoritas pajak di 
Indonesia untuk menelaah kembali kesesuaian kebijakan-kebijakan yang telah dilakukan selama pandemi COVID-19 dengan melihat kondisi negaranegara lainnya dan kondisi sosial-ekonomi di Indonesia.

\section{DAFTAR PUSTAKA (REFERENCES)}

Asher, M. G., \& Rajan, R. S. (2001). Globalization and tax systems: Implications for developing countries with particular reference to Southeast Asia. ASEAN economic bulletin, 18(1), 119-139.

Avi-Yonah, R. S. (2020). COVID-19 and US Tax Policy: What needs to change?. The Social Science Research Network Electronic Paper Collection SSRN 3584330.

Bureau of Internal Revenue. (2020). Revenue Memorandum Circular No. 34-2020: Suspending the running of the statute of limitations in the assessment and collection of taxes pursuant to section 223 of the National Internal Revenue Code of 1997, as amended, due to the declaration of a national emergency from the coronavirus disease (COVID-19) situation. Diakses dari https://www.bir.gov.ph/images/bir files/internal communications 2/RMCs/2020\%20RMCs/RMC \%20No.\%2034-2020.pdf.

Chua, Y. T. (2020). COVID-19 in Southeast Asia: The numbers. Diakses dari https://www.reportingasean.net/covid-19-casessoutheast-asia/ pada tangga 27 Oktober 2020.

Clemens, J., \& Veuger, S. (2020). Implications of the COVID-19 Pandemic for State Government Tax Revenues (No. w27426). National Bureau of Economic Research.

Darussalam. (2020). Peran pajak sebagai penyelamat dampak Covid-19. Diakses dari https://news.ddtc.co.id/peran-pajak-sebagaipenyelamat-dampak-covid-19-24258.

EY. (2020). The 2020 economic stimulus packagetackling the impact of COVID-19. Diakses dari https://www.ey.com/en my/news/2020/02/the2020-economic-stimulus-package-tackling-theimpact-of-covid-19.

Fauzi, M. A., \& Paiman, N. (2020). COVID-19 pandemic in Southeast Asia: intervention and mitigation efforts. Asian Education and Development Studies.

Guvenen, F., Kambourov, G., Kuruscu, B., OcampoDiaz, S., \& Chen, D. (2019). Use it or lose it: Efficiency gains from wealth taxation (No. w26284). National Bureau of Economic Research.

Horton, M., \& El-Ganainy, A. (2020). Fiscal policy: Taking and giving away. Diakses dari https://www.imf.org/external/pubs/ft/fandd/basi cs/fiscpol.htm.

Inland Revenue Authority of Singapore. (2020). COVID19 support measures and tax guidance. Diakses dari https://www.iras.gov.sg/irashome/COVID19-Support-Measures-and-Tax-Guidance/COVID19-Support-Measures-and-Tax-Guidance/.

Jayani, D. H. (2020). Covid-19 menjatuhkan ekonomi Asia Tenggara. Diakses dari https://katadata.co.id/ariayudhistira/infografik/5f 45ee727502e/covid-19-menjatuhkan-ekonomiasia-tenggara pada.

Kanniah, K. D., Zaman, N. A. F. K., Kaskaoutis, D. G., \& Latif, M. T. (2020). COVID-19's impact on the atmospheric environment in the Southeast Asia region. Science of the Total Environment, 736, 133.

Kementerian Keuangan Republik Indonesia. (2020). Ini 5 sektor usaha yang paling banyak menerima insentif perpajakan di masa COVID-19. Diakses dari

https://www.kemenkeu.go.id/publikasi/berita/ini -5-sektor-usaha-yang-paling-banyak-menerimainsentif-perpajakan-di-masa-covid19/\#: :text=Jakarta\%2C\%2025\%2F06\%2F2020,ser ta\%20akomodasi\%20dan\%20makan\%2Fminum.

KPMG. (2020). Myanmar: Tax developments in response to COVID-19. Diakses dari https://home.kpmg/xx/en/home/insights/2020/0 4/myanmar-tax-developments-in-response-tocovid-19.html.

Krailadsiri, S., \& Chaisechotes, S. (2020). Thailand announces tax measures to manage COVID-19 outbreak. Diakses dari https://www.internationaltaxreview.com/article/ b1ll768stgm7mv/thailand-announces-taxmeasures-to-manage-covid-19-outbreak.

Kurniati, D. (2020). Kamboja: Insentif pajak diperpanjang hingga akhir tahun. Diakses dari https://news.ddtc.co.id/insentif-pajakdiperpanjang-hingga-akhir-tahun24473?page $y=0$.

Landais, C., Saez, E., \& Zucman, G. (2020). A progressive European wealth tax to fund the European COVID response. VoxEU.

Mankiw, G. (2020). A proposal for social insurance during the pandemic. Diakses dari http://gregmankiw.blogspot.com/2020/03/aproposal-for-social-insurance-during.html.

Mardiasmo. (2018). Perpajakan Edisi Revisi. Yogyakarta: Andi.

Marron, D. (2020). If we give everybody cash to boost the coronavirus economy, let's tax it. Diakses dari https://www.taxpolicycenter.org/taxvox/if-wegive-everybody-cash-boost-coronaviruseconomy-lets-tax-it.

Nugroho, A. (2020). Ini negara-negara Asia Tenggara yang lakukan "lockdown" lagi!. Diakses dari https://www.kompas.tv/article/99229/ini- 
negara-negara-asia-tenggara-yang-lakukanlockdown-lagi.

OECD. (2020a). Tax and fiscal policy in response to the coronavirus crisis: Strengthening confidence and resilience. Diakses dari http://www.oecd.org/ctp/tax-policy/tax-andfiscal-policy-in-response-to-the-coronavirus-crisisstrengthening-confidence-and-resilience.htm

OECD. (2020b). Overview of country tax policy measures in response to Covid-19 crisis. Diakses dari http://www.oecd.org/tax/tax-policy/countryreviews-advice/ pada 22 Oktober 2020.

Orbitax. (2020). Vietnam provides tax payment relief for COVID-19. Diakses dari https://www.orbitax.com/news/archive.php/Viet nam-Provides-Tax-Payment-R-41797.

Pomerleau, K. (2020). Tax policy and the federal response to COVID-19. American Enterprise Institute (AEI).

Putri, G. S. (2020). WHO resmi sebut virus corona Covid19 sebagai pandemi global. Diakses dari https://www.kompas.com/sains/read/2020/03/1 2/083129823/who-resmi-sebut-virus-coronacovid-19-sebagai-pandemiglobal?page=all\#: :text=KOMPAS.com\%20\%2D\%2 0Organisasi\%20Kesehatan\%20Dunia,\%2C\%20AS\% 2C\%20hingga\%20Afrika\%20Selatan

Sohrabi, C., Alsafi, Z., O'Neill, N., Khan, M., Kerwan, A., Al-Jabir, A., \& Agha, R. (2020). World Health Organization declares global emergency: A review of the 2019 novel coronavirus (COVID19). International Journal of Surgery, 76, 71-76.

Tan, W. J. Z. X., Zhao, X., Ma, X., Wang, W., Niu, P., Xu, W., \& Wu, G.Z. (2020). A novel coronavirus genome identified in a cluster of pneumonia cases-Wuhan, China 2019-2020. China CDC Weekly, 2(4), 61-62.

Trading Economics. (2020). Indikator ekonomi negaranegara di dunia. Diakses dari https://tradingeconomics.com/countries

VDB Loi. (2020). COVID-19: The Lao PDR government announces new economic policy measures. Diakses dari http://www.vdbloi.com/laos publication/covid-19-the-lao-pdrgovernment-announces-new-economic-policymeasures/

Xu, Z., Shi, L., Wang, Y., Zhang, J., Huang, L., Zhang, C., \& Tai, Y. (2020). Pathological findings of COVID-19 associated with acute respiratory distress syndrome. The Lancet Respiratory Medicine, 8(4), 420-422.

Wittayanakorn, N., Nga, V. D. W., Sobana, M., Bahuri, N. F. A., \& Baticulon, R. E. (2020). Impact of COVID-
19 on Neurosurgical Training in Southeast Asia. World Neurosurgery, 1-14.

World Economic Forum. (2016). The ASEAN Economic Community: What you need to know. Diakses dari https://www.weforum.org/agenda/2016/05/asea n-economic-community-what-you-need-to-know/

Zhu, N., Zhang, D., Wang, W., Li, X., Yang, B., Song, J. and Niu, P. (2020). A novel coronavirus from patients with pneumonia in China, 2019. New England Journal of Medicine, 382(8), 727-733 